\title{
Blood group terminology 2004: from the International Society of Blood Transfusion committee on terminology for red cell surface antigens
}

G. L. Daniels, ${ }^{1}$ A. Fletcher, ${ }^{2}$ G. Garratty, ${ }^{3}$ S. Henry, ${ }^{4}$ J. Jørgensen, ${ }^{5}$ W. J. Judd, ${ }^{6}$ C. Levene, ${ }^{7}$ C. Lomas-Francis, ${ }^{8}$ J. J. Moulds, ${ }^{9}$ J. M. Moulds, ${ }^{10}$ M. Moulds, ${ }^{11}$ M. Overbeeke, ${ }^{12}$ M. E. Reid, ${ }^{8}$ P. Rouger, ${ }^{13}$ M. Scott, ${ }^{14}$ P. Sistonen, ${ }^{15}$ E. Smart, ${ }^{16}$ Y. Tani, $^{17}$

S. Wendel ${ }^{18}$ \& T. Zelinski ${ }^{19}$

${ }^{1}$ Bristol Institute for Transfusion Sciences, Bristol, UK

${ }^{2}$ Growing your Knowledge, Spit Junction, NSW, Australia

${ }^{3}$ American Red Cross Blood Services, Los Angeles-Orange Counties Region, Los Angeles, CA, USA

${ }^{4}$ Biotechnology Research Centre, Auckland University of Technology, Auckland, New Zealand

${ }^{5}$ Regional Blood Transfusion Center, Department of Clinical Immunology, University Hospital, Århus N, Denmark

${ }^{6}$ Department of Pathology, University Hospitals UH-2G332, Ann Arbor, Michigan, USA

${ }^{7}$ Reference Laboratory for Immunohematology and Blood Groups, National Blood Services Centre, Tel Hashomer, Israel

${ }^{8}$ New York Blood Center, New York, NY, USA

${ }^{9}$ Ortho-Clinical Diagnostics, Raritan, NJ, USA

${ }^{10}$ Drexel University College of Medicine, Philadelphia, PA, USA

${ }^{11}$ Gamma Biologicals Inc (subsidiary of Immunocor Inc), Houston, TX, USA

${ }^{12}$ Central Laboratory of the Netherlands Red Cross Blood Transfusion Service, Amsterdam, the Netherlands

${ }^{13}$ Centre national de Référence pour les Groupes sanguines (CNTS), Paris, France

${ }^{14}$ International Blood Group Reference Laboratory, Bristol, UK

${ }^{15}$ Finnish Red Cross Blood Transfusion Service, Helsinki, Finland

${ }^{16}$ South African National Blood Service, East Coast Region, Pinetown, South Africa

${ }^{17}$ Osaka Red Cross Blood Center, Osaka, Japan

${ }^{18}$ Blood Bank, Hospital Sirio-Libanes, São Paulo, Brazil

${ }^{19}$ Rh Laboratory, University of Manitoba, Winnipeg, Manitoba, Canada

\section{Vox Sanguinis}

Key words: blood groups, terminology, genetics.

\section{Introduction}

Human blood groups were discovered over 100 years ago. During the course of the 20th century, a variety of different styles of terminology has been used to denote them. The International Society of Blood Transfusion (ISBT) established a Working Party in 1980 to devise a genetically based numerical terminology for red cell surface antigens. In 1990, the Work-

Correspondence: Geoff Daniels, Bristol Institute for Transfusion Sciences, Southmead Road, Bristol, BS10 5ND, UK

E-mail: geoff.daniels@nbs.nhs.uk ing Party published a monograph describing a numerical terminology for 242 red cell antigens [1]. Another monograph listing 254 antigens was published in 1995 [2] and four brief updates have followed [3-6]. In the 9 years since the 1995 report, many amendments to the classification have been necessary: 30 new antigens have been identified and six new systems created. Since 1995, the genes for nine blood group systems have been identified, so that sequenced genes for all 29 systems are now available. All blood group system genes have been located on a specific region of a chromosome (Table 1). The current classification can be found at www.iccbba.com/ppage107.htm. 
Table 1 The blood group systems, the genes that encode them, their chromosomal locations, and associated CD numbers

\begin{tabular}{|c|c|c|c|c|c|c|}
\hline No. & System name & $\begin{array}{l}\text { System } \\
\text { symbol }\end{array}$ & Gene name $(s)^{a}$ & $\begin{array}{l}\text { Chromosomal } \\
\text { location }\end{array}$ & CD numbers & Refs \\
\hline 001 & $\mathrm{ABO}$ & ABO & $A B O$ & $9 q 34.2$ & & \\
\hline 002 & MNS & MNS & GYPA, GYPB, GYPE & $4 q 31.21$ & CD235 & \\
\hline 003 & $\mathrm{P}$ & $\mathrm{P} 1$ & & 22q11.2-qter & & \\
\hline 004 & $\mathrm{Rh}$ & $\mathrm{RH}$ & $R H D, R H C E$ & $1 \mathrm{p} 36.11$ & CD240 & \\
\hline 005 & Lutheran & $L U$ & $L U$ & $19 q 13.32$ & CD239 & \\
\hline 006 & Kell & KEL & KEL & $7 q 34$ & CD238 & \\
\hline 007 & Lewis & $\mathrm{LE}$ & FUT3 & $19 \mathrm{p} 13.3$ & & \\
\hline 008 & Duffy & $\mathrm{FY}$ & $F Y$ & $1 q 23.2$ & CD234 & \\
\hline 009 & Kidd & JK & SLC14A1 & $18 q 12.3$ & & {$[7,8]$} \\
\hline 010 & Diego & DI & SLC4A1 & $17 q 21.31$ & CD233 & \\
\hline 011 & Yt & YT & ACHE & $7 q 22.1$ & & \\
\hline 012 & $\mathrm{Xg}$ & $X G$ & $X G, M I C 2$ & Хp22.33, Yp11.3 & CD99 $^{b}$ & \\
\hline 013 & Scianna & SC & ERMAP & $1 \mathrm{p} 34.2$ & & {$[9]$} \\
\hline 014 & Dombrock & DO & DO & $12 \mathrm{p} 12.3$ & & {$[10,11]$} \\
\hline 015 & Colton & $\mathrm{CO}$ & $A Q P 1$ & $7 p 14.3$ & & \\
\hline 016 & Landsteiner-Wiener & $\mathrm{LW}$ & ICAM4 & 19p13.2 & CD242 & \\
\hline 017 & Chido/Rodgers & $\mathrm{CH} / \mathrm{RG}$ & $C 4 A, C 4 B$ & $6 p 21.3$ & & \\
\hline 018 & $\mathrm{H}$ & $\mathrm{H}$ & FUT1 & $19 q 13.33$ & CD173 & \\
\hline 019 & $\mathrm{Kx}$ & XK & $X K$ & Xp21.1 & & \\
\hline 020 & Gerbich & GE & GYPC & $2 q 14.3$ & CD236 & \\
\hline 021 & Cromer & CROM & $D A F$ & $1 q 32.2$ & CD55 & \\
\hline 022 & Knops & $\mathrm{KN}$ & $C R 1$ & $1 q 32.2$ & CD35 & \\
\hline 023 & Indian & IN & $C D 44$ & $11 \mathrm{p} 13$ & CD44 & \\
\hline 024 & Ok & OK & $B S G$ & $19 \mathrm{p} 13.3$ & CD147 & [12] \\
\hline 025 & Raph & RAPH & CD151 & $11 \mathrm{p} 15.5$ & CD151 & [13-15] \\
\hline 026 & John Milton Hagen & $\mathrm{JMH}$ & SEMA7A & $15 q 24.1$ & CD108 & {$[16,17]$} \\
\hline 027 & I & I & GCNT2 & $6 \mathrm{p} 24.2$ & & {$[18,19]$} \\
\hline 028 & Globoside & GLOB & B3GALT3 & $3 q 26.1$ & & {$[20,21]$} \\
\hline 029 & Gill & GIL & $A Q P 3$ & $9 p 13.3$ & & {$[22,23]$} \\
\hline
\end{tabular}

${ }^{\mathrm{a} A s}$ recognized by the HUGO Gene Nomenclature Committee (www.gene.ucl.ac.uk/nomenclature/); ${ }^{\mathrm{b}} \mathrm{MIC2}$ product.

The purpose of this monograph is to describe the ISBT terminology for red cell surface antigens and to tabulate the complete current version of the classification. Much of the information provided in the 1995 monograph [1] is reiterated here so that referral back will not generally be required, but only references published after 1995 are provided.

\section{The ISBT numerical terminology}

The mandate of the Committee is to provide a numerical terminology for red cell surface antigens. By definition, these antigens must be defined serologically by the use of a specific antibody. Numerical designations and blood group symbols cannot be allocated to nucleotide or amino acid sequences or polymorphisms, even though the presence of specific blood group antigens may be indicated by these techniques. All antigens receiving ISBT numbers must have been shown to be inherited characters.
All authenticated antigens fall into one of four classifications: systems; collections; low-incidence antigens (700 series); and high-incidence antigens (901 series). A blood group system consists of one or more antigens controlled at a single gene locus, or by two or more very closely linked homologous genes with little or no observable recombination between them. Each system has been shown to be genetically discrete from every other system. Collections consist of serologically, biochemically, or genetically related antigens, which do not fit the criteria required for system status. The 700 and 901 series contain low- and high-incidence antigens, respectively, which cannot be included in a system or collection.

Each antigen belonging to a blood group system is identified by a six-digit number (Tables 1-3). The first three digits represent the system (e.g. 006 for Kell) and the second three the specificity (e.g. 006003 for $\mathrm{Kp}^{\mathrm{a}}$ ). Alternatively, the system symbol followed by the antigen number may be used (e.g. KEL003 or, more usually, KEL3 as sinistral zeros may be 
Table 2 Examples of antigen, phenotype, gene, and genotype designations in International Society of Blood Transfusion (ISBT) and traditional terminologies

\begin{tabular}{lll}
\hline & & $\begin{array}{l}\text { Traditional and } \\
\text { 'popular' alternative }\end{array}$ \\
\hline Antigen & $\mathrm{LU} 1$ or 005001 & $\mathrm{Lu}$ \\
Phenotype & $\mathrm{LU}:-1,2$ & $\mathrm{Lu}(\mathrm{a}-\mathrm{b}+)$ \\
Gene & $L U^{*} 1$ & $L u^{a}$ \\
Genotype & $L U^{*} 2 / 2$ & $L u^{b} / L u^{b}$ \\
& $L U^{*} 1,8 / 2,14$ & $L u^{a} L u^{8} / L u^{b} L u^{14}$ \\
\hline
\end{tabular}

removed). Phenotypes are represented by the system symbol, followed by a colon, followed by a list of antigens separated by commas. Those antigens shown to be absent are preceded by a minus sign (e.g. KEL:-1,2,-3,4). Genes are designated by the system symbol, followed by an asterisk, followed by the antigen number (e.g. $K E L^{*} 3$ ). Genotypes have the system symbol, followed by an asterisk, followed by alleles or haplotypes separated by a slash (e.g. $K E L^{*} 2,3 / 2,4$ ). Amorph or null genes are represented by a zero (e.g. $K E L^{*} 2,3 / 0$ ). Gene and genotype designations are italicized (or underlined). Antigen, phenotype, gene and genotype designations for collections are constructed in the same way. For the 700 and 901 series, 700 or 901 replaces the system symbol.

\section{Symbols for gene loci}

The symbol for a gene or cluster of genes controlling a blood group system is the italicized symbol for the system (e.g. $\mathrm{CO}$ for the gene controlling the Colton system). The genes controlling all of the blood group systems have been cloned and, in many cases, the gene locus has an alternative symbol (Table 1), usually because the protein product of the gene is of known function or the gene had an existing symbol before the association with the blood group was known. Examples: the genes controlling expression of the Diego and Kidd antigens encode solute carriers with the symbols SLC4A1 and SLC14A1, respectively; the Yt antigens are encoded by the acetylcholinesterase gene ACHE; the Colton and GIL antigens are encoded by $A Q P 1$ and $A Q P 3$, respectively, the genes producing the water transporters Aquaporin-1 and -3; the presence of $\mathrm{H}$ antigen on the red cells is determined by an $\alpha-1,2-$ fucosyltransferase gene, FUT1; and the presence of Lewis antigens on red cells is indirectly determined by an $\alpha-1$, 3/4-fucosyltransferase gene, FUT3. At least two genes, $R H D$ and RHCE, govern the Rh antigens, and three genes, GYPA, $G Y P B$, and GYPE, are involved in the expression of antigens of the MNS system. The symbol for the gene governing a serologically determined blood group antigen comprises the system symbol and antigen number (e.g. $R H^{*} 1, D I^{*} 2$, $C 0^{*} 1$ ). When the gene encoding a blood group antigen is determined by non-serological means, such as nucleotide sequencing, the alternative symbol should be used (e.g. $S L C 14 A 1$ instead of $J K$, and DAF instead of CROM) and allele designations should conform to the established terminologies employed for nucleotide polymorphisms (see refs 24,25 and www.bioc.aecom.yu.edu/bgmut/index.htm).

It is important to remember that when symbols such as $R H^{*} 2$ or $M N S^{*} 10$ are used, the symbol does not necessarily represent a single defined gene, but one of a cluster of genes or a hybrid of two genes.

\section{A 'popular', alternative terminology}

The numerical terminology was devised primarily for computer storage of information on blood group antigens and to provide a framework for a genetical classification. The numerical terminology is not suitable for everyday communication and many scientists working in the field of human blood groups prefer not to use it in publications. This has led to a variety of alternative names being used for some blood group antigens. In an attempt to introduce some uniformity, a recommended list of alternative names for antigens is provided in Table 3. In most cases, the name or symbol is identical to that originally published, but in a few cases the more commonly used name is provided. In addition, there are recommended formats for describing phenotypes in the alternative terminology. These mostly employ traditional terminology, and examples are shown in Table 4. A more complete list has been published previously [4].

\section{Blood group systems}

There are currently 29 systems containing a total of 245 antigens (Tables 1 and 3).

\section{Modifications since 1995: existing systems}

002, the MNS system

Five new antigens have been added. Absence of the highincidence antigen MNS39 (ENEP) and presence of the lowincidence antigen MNS41 (HAG) is associated with an Ala65Pro substitution in glycophorin A (GPA) [26]. The absence of MNS42 (ENAV, previously AVIS) and the presence of MNS43 (MARS), its low-incidence antithetical antigen, results from a Gln63Lys substitution in GPA [27]. Both of these substitutions are associated with abnormal expression of DI4 (Wr $\left.{ }^{b}\right)$. MNS40 (ENEH) is absent from glycophorin A of the phenotype GP.Vw (Mi.I); the glycophorin A has a Thr28Met substitution and expresses MNS9 (Vw) antigen [28].

003, the $P$ system

Evidence was presented suggesting that the same transferase encoded by $A 4 G A L T$, is responsible for the biosynthesis of 
Table 3 Antigens of the blood group systems

\begin{tabular}{|c|c|c|c|c|c|c|c|c|c|c|c|c|c|c|c|c|c|c|c|c|c|c|c|c|c|}
\hline \multirow[b]{2}{*}{ System } & & \multicolumn{24}{|c|}{ Antigen number } \\
\hline & & 001 & 002 & 003 & 004 & 005 & 006 & 007 & 008 & 009 & 010 & 011 & 012 & 013 & 014 & 015 & 016 & 017 & 018 & 019 & 020 & 021 & 022 & 023 & 024 \\
\hline 001 & $\mathrm{ABO}$ & A & B & $A, B$ & A1 & $\ldots$ & & & & & & & & & & & & & & & & & & & \\
\hline 002 & MNS & $M$ & $\mathrm{~N}$ & S & s & $\mathrm{U}$ & $\mathrm{He}$ & $\mathrm{Mi}^{\mathrm{a}}$ & $\mathrm{M}^{\mathrm{c}}$ & $V_{w}$ & Mur & $\mathrm{M}^{g}$ & $\mathrm{Vr}$ & $\mathrm{M}^{\mathrm{e}}$ & $\mathrm{Mt}^{\mathrm{a}}$ & $\mathrm{St}^{\mathrm{a}}$ & $\mathrm{Ri}^{\mathrm{a}}$ & $\mathrm{Cl}^{\mathrm{a}}$ & $\mathrm{Ny}^{\mathrm{a}}$ & Hut & Hil & $\mathrm{M}^{\mathrm{v}}$ & Far & $s^{D}$ & Mit \\
\hline 003 & $P$ & P1 & $\ldots$ & $\ldots$ & & & & & & & & & & & & & & & & & & & & & \\
\hline 004 & $\mathrm{RH}$ & $\mathrm{D}$ & C & $\mathrm{E}$ & c & e & $\mathrm{f}$ & $\mathrm{Ce}$ & $\mathrm{C}^{\mathrm{w}}$ & $C^{x}$ & V & $\mathrm{E}^{\mathrm{w}}$ & G & $\ldots$ & $\ldots$ & $\ldots$ & $\ldots$ & $\mathrm{Hr}_{0}$ & $\mathrm{Hr}$ & $h r^{S}$ & VS & $C^{G}$ & CE & $D^{w}$ & $\ldots$ \\
\hline 005 & LU & $\mathrm{Lu}^{\mathrm{a}}$ & $\mathrm{Lu}^{\mathrm{b}}$ & Lu3 & Lu4 & Lu5 & Lu6 & Lu7 & Lu8 & Lu9 & $\ldots$ & Lu11 & Lu12 & Lu13 & Lu14 & $\ldots$ & Lu16 & Lu17 & $A u^{a}$ & $A u^{b}$ & Lu20 & Lu21 & & & \\
\hline 006 & KEL & $\mathrm{K}$ & k & $\mathrm{Kp}^{\mathrm{a}}$ & $\mathrm{Kp}^{\mathrm{b}}$ & $\mathrm{Ku}$ & $\mathrm{Js}^{\mathrm{a}}$ & $\mathrm{Js}^{\mathrm{b}}$ & $\ldots$ & $\ldots$ & $\mathrm{Ul}^{\mathrm{a}}$ & K11 & $\mathrm{K} 12$ & $\mathrm{~K} 13$ & K14 & $\ldots$ & $\mathrm{K} 16$ & K17 & K18 & K19 & $\mathrm{Km}$ & $\mathrm{Kp}^{\mathrm{c}}$ & K22 & $\mathrm{K} 23$ & K24 \\
\hline 007 & LE & $\mathrm{Le}^{\mathrm{a}}$ & $\mathrm{Le}^{\mathrm{b}}$ & $\mathrm{Le}^{\mathrm{ab}}$ & $\mathrm{Le}^{\mathrm{bH}}$ & ALe $^{b}$ & $\mathrm{BLe}^{\mathrm{b}}$ & & & & & & & & & & & & & & & & & & \\
\hline 008 & FY & $\mathrm{Fy}^{\mathrm{a}}$ & $\mathrm{Fy}^{\mathrm{b}}$ & Fy3 & Fy4 & Fy5 & Fy6 & & & & & & & & & & & & & & & & & & \\
\hline 009 & JK & $\mathrm{Jk}^{\mathrm{a}}$ & $\mathrm{Jk}^{\mathrm{b}}$ & $\mathrm{Jk} 3$ & & & & & & & & & & & & & & & & & & & & & \\
\hline 010 & DI & $\mathrm{Di}^{\mathrm{a}}$ & $\mathrm{Di}^{\mathrm{b}}$ & $W r^{a}$ & $\mathrm{Wr}^{\mathrm{b}}$ & $W^{a}$ & $\mathrm{Rb}^{\mathrm{a}}$ & WARR & ELO & Wu & $B p^{a}$ & $\mathrm{Mo}^{\mathrm{a}}$ & $\mathrm{Hg}^{\mathrm{a}}$ & $\mathrm{Vg}^{\mathrm{a}}$ & $\mathrm{Sw}^{\mathrm{a}}$ & BOW & NFLD & $\mathrm{Jn}^{\mathrm{a}}$ & KREP & $\operatorname{Tr}^{\mathrm{a} *}$ & $\mathrm{Fr}^{\mathrm{a}}$ & SW1 & & & \\
\hline 011 & YT & $\mathrm{Yt}^{\mathrm{a}}$ & $\mathrm{Yt}^{\mathrm{b}}$ & & & & & & & & & & & & & & & & & & & & & & \\
\hline 012 & $X G$ & $\mathrm{Xg}^{\mathrm{a}}$ & CD99 & & & & & & & & & & & & & & & & & & & & & & \\
\hline 013 & SC & Sc1 & Sc2 & Sc3 & $\mathrm{Rd}$ & STAR & & & & & & & & & & & & & & & & & & & \\
\hline 014 & DO & $\mathrm{Do}^{\mathrm{a}}$ & $\mathrm{Do}^{\mathrm{b}}$ & $\mathrm{Gy}^{\mathrm{a}}$ & Hy & $\mathrm{Jo}^{\mathrm{a}}$ & & & & & & & & & & & & & & & & & & & \\
\hline 015 & CO & $\mathrm{Co}^{\mathrm{a}}$ & $\mathrm{Co}^{\mathrm{b}}$ & Co3 & & & & & & & & & & & & & & & & & & & & & \\
\hline 016 & LW & $\ldots$ & $\ldots$ & $\ldots$ & $\ldots$ & $\mathrm{LW}^{\mathrm{a}}$ & $\mathrm{LW}^{\mathrm{ab}}$ & $\mathrm{LW}^{\mathrm{b}}$ & & & & & & & & & & & & & & & & & \\
\hline 017 & $\mathrm{CH} / \mathrm{RG}$ & Ch1 & Ch2 & Ch3 & Ch4 & Ch5 & Ch6 & WH & & & & $\operatorname{Rg} 1$ & Rg2 & & & & & & & & & & & & \\
\hline 018 & $\mathrm{H}$ & $\mathrm{H}$ & & & & & & & & & & & & & & & & & & & & & & & \\
\hline 019 & $\mathrm{XK}$ & $\mathrm{Kx}$ & & & & & & & & & & & & & & & & & & & & & & & \\
\hline 020 & GE & $\ldots$ & Ge2 & Ge3 & Ge4 & Wb & $L s^{a}$ & $\mathrm{An}^{\mathrm{a}}$ & $\mathrm{Dh}^{\mathrm{a}}$ & GEIS & & & & & & & & & & & & & & & \\
\hline 021 & CROM & $\mathrm{Cr}^{\mathrm{a}}$ & $\mathrm{Tc}^{\mathrm{a}}$ & $\mathrm{Tc}^{\mathrm{b}}$ & $\mathrm{Tc}^{\mathrm{c}}$ & $\mathrm{Dr}^{\mathrm{a}}$ & $\mathrm{ES}^{\mathrm{a}}$ & IFC & WES ${ }^{a}$ & $W_{E S}^{b}$ & UMC & GUTI & SERF & ZENA & & & & & & & & & & & \\
\hline 022 & $\mathrm{KN}$ & $\mathrm{Kn}^{\mathrm{a}}$ & $K n^{b}$ & $\mathrm{McC}^{\mathrm{a}}$ & SI1 & $Y^{a}$ & $\mathrm{McC}^{\mathrm{b}}$ & $\mathrm{SI} 2$ & $\mathrm{SI} 3^{*}$ & & & & & & & & & & & & & & & & \\
\hline 023 & IN & $\ln ^{a}$ & $\ln ^{b}$ & & & & & & & & & & & & & & & & & & & & & & \\
\hline 024 & OK & $0 k^{\mathrm{a}}$ & & & & & & & & & & & & & & & & & & & & & & & \\
\hline 025 & RAPH & MER2 & & & & & & & & & & & & & & & & & & & & & & & \\
\hline 026 & JMH & $\mathrm{JMH}$ & & & & & & & & & & & & & & & & & & & & & & & \\
\hline 027 & I & I & & & & & & & & & & & & & & & & & & & & & & & \\
\hline 028 & GLOB & $\mathrm{P}$ & & & & & & & & & & & & & & & & & & & & & & & \\
\hline \multirow[t]{2}{*}{029} & GIL & GIL & & & & & & & & & & & & & & & & & & & & & & & \\
\hline & & $\underline{025}$ & 026 & 027 & 028 & 029 & 030 & 031 & 032 & 033 & 034 & 035 & 036 & 037 & 038 & 039 & 040 & 041 & 042 & 043 & 044 & 045 & 046 & & \\
\hline 002 & MNS & Dantu & Hop & Nob & $\mathrm{En}^{\mathrm{a}}$ & En ${ }^{a} \mathrm{KT}$ & 'N' & Or & DANE & TSEN & MINY & MUT & SAT & ERIK & $0 s^{a}$ & ENEP & ENEH & HAG & ENAV & MARS & & & & & \\
\hline 004 & $\mathrm{RH}$ & $\ldots$ & c-like & $\mathrm{cE}$ & $\mathrm{hr}^{\mathrm{H}}$ & $\mathrm{Rh} 29$ & $\mathrm{Go}^{\mathrm{a}}$ & $\mathrm{hr}^{\mathrm{B}}$ & Rh32 & Rh33 & $\mathrm{Hr}^{\mathrm{B}}$ & Rh35 & $\mathrm{Be}^{\mathrm{a}}$ & Evans & $\ldots$ & Rh39 & Tar & Rh41 & Rh42 & Crawford & Nou & Riv & $\mathrm{Sec}$ & & \\
\hline \multirow[t]{2}{*}{006} & KEL & VLAN & TOU & RAZ & VONG & & & & & & & & & & & & & & & & & & & & \\
\hline & & 047 & 048 & 049 & 050 & 051 & 052 & 053 & 054 & 055 & 056 & & & & & & & & & & & & & & \\
\hline 004 & $\mathrm{RH}$ & Dav & JAL & STEM & FPTा & MAR & BARC & JAHK & DAK & LOCR & CENR & & & & & & & & & & & & & & \\
\hline
\end{tabular}


Table 4 Examples of the format recommended for phenotype designation in the alternative, 'popular' terminology

\begin{tabular}{|c|c|}
\hline Numerical terminology & Alternative terminology \\
\hline ABO:-1,-2,-3 & 0 \\
\hline$A B 0: 1,-2,3,4$ & $A_{1}$ \\
\hline ABO: $1,-2,3,-4$ & $\mathrm{~A}_{2}$ \\
\hline \multirow[t]{2}{*}{ MNS:1,2,-3,4,5,-6,7 } & $\mathrm{M}+\mathrm{N}+\mathrm{S}-\mathrm{s}+\mathrm{U}+\mathrm{He}-\mathrm{Mi}(\mathrm{a}+)$ (in ISBT order) \\
\hline & Symbols such as Mi.III or GP.Mur, En(a-), M $^{k}$ are also acceptable \\
\hline$P: 1$ & $\mathrm{P} 1+$ or $\mathrm{P}_{1}$ \\
\hline P:-1 & $\mathrm{P} 1-$ or $\mathrm{P}_{2}$ (if shown to be GLOB:1) \\
\hline \multirow[t]{5}{*}{$\mathrm{RH}: 1,2,-3,4,5,-8,32,33,-36$} & $\mathrm{D}+\mathrm{C}+\mathrm{E}-\mathrm{C}+\mathrm{e}+\mathrm{C}^{\mathrm{w}}-\mathrm{Rh}:-32,33 \mathrm{Be}(\mathrm{a}-)$ (in ISBT order) \\
\hline & The order D C c E e would be an acceptable alternative. Probable genotypes as \\
\hline & phenotypes (e.g. $\mathrm{R}_{1} \mathrm{R}_{2}$ or $\mathrm{DCe} / \mathrm{DcE} ; \mathrm{R}_{1} r \mathrm{C}^{\mathrm{w}}+$ or $\mathrm{DCe} / \mathrm{dce} \mathrm{C}_{+}^{\mathrm{w}}$ ) are acceptable, providing \\
\hline & it is made clear that they are only probable genotypes based on haplotype frequencies. \\
\hline & Null and mod phenotypes: $R h_{\text {nulli }} ; R h_{\text {mod }}$ \\
\hline \multirow[t]{2}{*}{ LU:-1,2,3,4 } & $L u(a-b+) L u: 3,4$ \\
\hline & Null phenotype: $\mathrm{Lu}_{\text {null }}$ or $\mathrm{Lu}(\mathrm{a}-\mathrm{b}-)$ \\
\hline \multirow{2}{*}{ KEL:- $1,2,-3,4,5,-6,7,11,12,13,-17,-21$} & $K-k+K p(a-b+c-) K u+J s(a-b+) K: 11,12,13,-17,-21$ \\
\hline & Null and mod phenotypes: $\mathrm{K}_{\mathrm{o}}$ or Kell $\mathrm{Kull}_{1} ; \mathrm{K}_{\text {mod }}$ \\
\hline $\mathrm{FY}: 1,2,3$ & Fy $(a+b+) F y: 3$ \\
\hline \multirow[t]{2}{*}{$\mathrm{FY}:-1,-2,-3$} & Fy(a-b-) Fy:-3 \\
\hline & $\mathrm{Fy}^{\mathrm{x}}$ may be used as a phenotype \\
\hline DI: $1,2,-3,4,-5,-6,-7$ & $\operatorname{Di}(a+b+)$ Wr(a-b+) Wd(a-) Rb(a-) WARR- \\
\hline $\mathrm{D} 0: 1,2,3,4,5$ & $\mathrm{Do}(\mathrm{a}+\mathrm{b}+) \mathrm{Gy}(\mathrm{a}+) \mathrm{Hy}+\mathrm{Jo}(\mathrm{a}+)$ \\
\hline$L W: 5,6,-7$ & $\operatorname{LW}(a+b-) L W(a b+)$ \\
\hline $\mathrm{CH} / \mathrm{RG}: 1,2,-7,11,12$ & Ch:1,2 WH- Rg:1,2 \\
\hline \multirow[t]{3}{*}{$\mathrm{H}:-1$} & $\mathrm{H}$ - The symbol $\mathrm{O}_{\mathrm{h}}$ may be used for the true Bombay phenotype (red cells totally \\
\hline & H-deficient, ABH non-secretors). Otherwise the terms 'Red cell H-deficient \\
\hline & secretor' and 'Red cell H-deficient non-secretor' are recommended. \\
\hline XK:-1 & Kx- or McLeod \\
\hline $\mathrm{GE}: 2,3,4,-5,-6,-7,-8,-9$ & Ge:2,3,4 Wb- Ls(a-) An(a-) Dh(a-) GEIS- \\
\hline GE:-2,-3,4 & Ge:-2,-3,4 or Gerbich phenotype \\
\hline GE:-2,3,4 & Ge:-2,3,4 or Yus phenotype \\
\hline $\mathrm{GE}:-2,-3,-4$ & Ge:-2,-3,-4 or Leach phenotype \\
\hline RAPH:1 & MER2+ \\
\hline $\mathrm{I}: 1$ & I adult \\
\hline I:-1 & i adult or cord \\
\hline
\end{tabular}

both $\mathrm{P} 1$ and $\mathrm{P}^{\mathrm{k}}$ (209002 of the GLOB Collection) [29]. However, because of reports of conflicting evidence [30] (L. Tilley, G. Daniels, unpublished) $\mathrm{P}^{\mathrm{k}}$ has not joined the P system.

004, the Rh system

Five antigens of low incidence have been added: RH52 (BARC) is produced by most $D^{V I} C$ e haplotypes, but is not produced by $D^{V I} c E$ haplotypes [31]; RH53 (JAHK) is associated with the rare Rh phenotype $\mathrm{r}^{\mathrm{G}}$ [32]; RH54 (DAK) with DIIIa, DOL, and some other rare Rh phenotypes [33]; RH55 (LOCR, previously 700053) with weak expression of RH4 (c) and RH5 (e) [34]; and RH56 (CENR) with an RHCE-D hybrid gene associated with RH8 $\left(\mathrm{C}^{\mathrm{w}}\right)$ and altered expression of RH2 (C) and RH5 (e) [35].

A new terminology has been devised for epitopes of RH1 (D) [36]. Basically, each epitope has two numbers, one representing the conventional epD1 to epD9 system proposed by
Lomas et al. [37], the other representing subdivisions of those numbers. The complete numerical terminology for epD1 is 004001.001.001 (abbreviated to epD1.1) and the epD1 subsplit caused by DFR is 004001.001.002 (epD1.2). Partial D antigens will be designated by up to four upper case letters or Roman numerals on the line; for example DIIIa, DIV, DHAR, DFR.

\section{5, the Lutheran system}

Absence of a new Lutheran antigen of high incidence, LU21, is associated with homozygosity for an $L U$ mutation encoding Asp94Glu [38].

\section{6, the Kell system}

KEL25 (VLAN) and KEL28 (VONG) are low-incidence antigens associated with Arg248Gln and Arg248Trp, respectively, in the Kell glycoprotein [39,40]. KEL26 (TOU) and KEL27 (RAZ) 
are antigens of high incidence, absent from the Kell glycoprotein with Arg406Gln [41] and Glu299Lys [39] substitutions, respectively.

\section{7, the Lewis system}

Three antigens, previously known for many years, were added to this system. LE4 $\left(\mathrm{Le}^{\mathrm{bH}}\right)$ is defined by antibodies that react with LE:2 [Le(b+)] cells, but only when $\mathrm{H} 1(\mathrm{H})$ is strongly expressed (group 0 and $A_{2}$ phenotypes). LE5 (ALe ${ }^{b}$ ) and LE6 $\left(\mathrm{BLe}^{\mathrm{b}}\right)$ are expressed when A type 1 and $\mathrm{B}$ type 1 are modified by the product of the Lewis gene, FUT3 [42].

\section{0, the Diego system}

Seventeen new antigens have been added, all of low incidence and all associated with mutations in SLC4A1 encoding amino acid substitutions in the erythrocyte anion exchanger (Table 5). The DI19 designation for $\operatorname{Tr}^{\mathrm{a}}$ is still provisional because only one case was analysed.

\section{2, the Xg system}

CD99, a glycoprotein encoded by a gene on both $\mathrm{X}$ and $\mathrm{Y}$ chromosomes, is recognized by monoclonal antibodies and human alloantibodies [54,55]. MIC2, the structural gene for CD99, is closely linked to $X G$ and shares substantial sequence homology with XG. Consequently, CD99 became XG2.

\section{3, the Scianna system}

Following the discovery that the Scianna antigens are expressed by the red cell adhesion protein, human ERMAP, expression of the low-incidence antigen, 700015 (Rd), was found to be associated with a mutation in ERMAP encoding

Table 5 Antigens of the Diego System assigned since 1995

\begin{tabular}{|c|c|c|c|c|}
\hline Antigen & & $\begin{array}{l}\text { Previous } \\
\text { number }\end{array}$ & $\begin{array}{l}\text { Amino acid } \\
\text { substitution }\end{array}$ & References \\
\hline DI5 & $W d^{a}$ & 700030 & Val557Met & {$[43,44]$} \\
\hline DI6 & $\mathrm{Rb}^{\mathrm{a}}$ & 700027 & Pro548Leu & {$[44]$} \\
\hline DI7 & WARR & 700055 & Thr552lle & {$[45]$} \\
\hline DI8 & ELO & 700051 & Arg432Trp & {$[46,47]$} \\
\hline DI9 & Wu & 700013 & Gly565Ala & {$[48]$} \\
\hline DI10 & $\mathrm{Bp}^{\mathrm{a}}$ & 700010 & Asn569Lys & {$[47]$} \\
\hline DI11 & $\mathrm{Mo}^{\mathrm{a}}$ & 700022 & Arg656His & {$[47]$} \\
\hline DI12 & $\mathrm{Hg}^{\mathrm{a}}$ & 700034 & Arg656Cys & {$[47]$} \\
\hline DI13 & $\mathrm{Vg}^{\mathrm{a}}$ & 700029 & Tyr555His & {$[47]$} \\
\hline DI14 & $S w^{\mathrm{a}}$ & 700004 & Arg646GIn or Trp & {$[49]$} \\
\hline DI15 & BOW & 700046 & Pro561Ser & {$[47,50,51]$} \\
\hline DI16 & NFLD & 700037 & Glu429Asp, Pro561Ala & {$[51]$} \\
\hline DI17 & $\mathrm{Jn}^{\mathrm{a}}$ & 700014 & Pro566Ser & {$[52]$} \\
\hline DI18 & KREP & & Pro566Ala & [50] \\
\hline DI19 & $\operatorname{Tr}^{\mathrm{a} *}$ & 700008 & Lys551Asn & [44] \\
\hline DI20 & $\mathrm{Fr}^{\mathrm{a}}$ & 700026 & Glu480Lys & [53] \\
\hline $\mathrm{DI} 21$ & SW1 & 700041 & Arg646Trp & [49] \\
\hline
\end{tabular}

Pro60Ala [9]. 700015 has become SC4. A new antigen of high incidence, STAR, is associated with Glu47Lys in ERMAP [56] and numbered SC5.

018 , the Hh system

The system name has been changed to $\mathrm{H}$.

020, the Gerbich system

A new antigen of low incidence, GEIS, associated with Thr32Asn in GPC and Thr11Asn in GPD [57], has been numbered GE9.

\section{1, the Cromer system}

Three new antigens of high incidence have been added: CROM11 (GUTI) [58], CROM12 (SERF) [59], and CROM13 (ZENA) [60] are associated with Arg206His, Pro182Leu and His208Gln in CD55, respectively.

\section{2, the Knops system}

Three new antigens have been added: KN6 to KN8. KN6 $\left(\mathrm{McC}^{\mathrm{b}}\right)$ represents Lys1590Glu in CD35, which is also associated with the absence of KN3 $\left(\mathrm{McC}^{\mathrm{a}}\right)$ [61]. KN4 (previously $\mathrm{Sl}^{\mathrm{a}}$, now S11) requires Arg1601 on CD35, KN7 (previously Vil, now S12) requires Gly1601, and KN8 (Sl3) requires both Arg1601 and Ser1610 [61,62]. The number KN8 is provisional because further complications are predicted.

\section{Modifications since 1995: new systems}

024, the Ok system

The high-incidence antigen $\mathrm{OK} 1\left(\mathrm{Ok}^{\mathrm{a}}\right.$, previously 901006) became the sole antigen of the Ok system following identification of the gene $(B S G)$ encoding the protein and of the amino acid substitution (Glu92Lys) responsible for the OK:-1 phenotype [12].

\section{5, the Raph system}

This new system contains one antigen: RAPH1 (MER2, previously 901011). Distinction of RAPH from the other blood group systems was demonstrated by family studies and by the positioning of CD151, the controlling gene, at 11p15.5 [13-15].

\section{6, the John Milton Hagen system}

JMH1 (JMH, previously 901007) is carried on the semaphorin CD108 [16]. The gene encoding CD108, SEMA7A, is located on the long arm of chromosome 15 [17], which distinguishes JMH1 from all existing blood group systems. JMH1 represents the antigen detected by antibodies produced by JMH:-1 individuals.

027, the I system

GCNT2, the gene encoding the $N$-acetylglucosaminyltransferase responsible for converting i-active straight chains to 
I-active branched chains, has been cloned and some mutations responsible for the i adult phenotype identified [18,19]. I1 antigen (I, previously 207001) is the only antigen of the I system. The i antigen, the precursor of I1, provisionally remains as 207002 .

\section{8, the Globoside system}

The gene (B3GALT3) encoding the $N$-acetylgalactosaminyltransferase (globoside synthase) responsible for converting $\mathrm{P}^{\mathrm{k}}$ (209002) to P (previously 209001, globoside) has been cloned and inactivating mutations responsible for the $\mathrm{P}^{\mathrm{k}}(\mathrm{P}$ negative) phenotype have been identified [20,21]. $\mathrm{P}$ has become GLOB1, the only antigen of the Globoside system.

029, the GIL system

GIL1, the only antigen of the GIL system, is an antigen of high incidence located on the glycerol transporter aquaporin 3, and the GIL:-1 phenotype results from an inactivating mutation within the $A Q P 3$ gene [22,23]. AQP3 is on chromosome $9 \mathrm{p} 13$, so GIL is genetically discrete from all other blood group systems.

\section{Guidelines for the establishment of new blood group systems}

For an antigen to form a new blood group system it must be defined by a human alloantibody, be an inherited character, the gene encoding it must have been identified and sequenced, and its chromosomal location must be known. In addition, the gene must be different from, and not a closely linked homologue of, all other genes encoding antigens of existing blood group systems.

All established blood group systems meet these criteria.

\section{Guidelines for the inclusion of a new specificity in an established system}

All antigens awarded an ISBT number must have been shown to be inherited, and at least one of the following four criteria must be met.

(1) An antithetical relationship between a new antigen and one already assigned to the system.

(2) Demonstration that expression of the antigen is associated with a variation in the nucleotide sequence of the gene controlling the system.

(3) Evidence, from a linkage analysis of family data, that the controlling allele is probably a newly recognized form of the pertinent gene, and supporting serological or biochemical information.

(4) Demonstration that an antigen is located on a protein or glycoprotein that carries other antigens belonging to the system. It must be remembered, however, that this could result from post-translational modification of a gene product, such as glycosylation, which would not support inclusion within the system.

\section{Blood group collections}

There are six blood group collections (Table 6).

A new Collection, 211 or Vel, was created to include two serologically related antigens of high incidence, Vel (VEL1, previously 901001) and ABTI (VEL2, previously 901015) $[63,64]$.

An antibody produced by a patient with ER:-1,-2 red cells and with the characteristics of antibodies of the ER Collection reacted with ER:1,-2, ER:-1,2, and the only other example of ER:-1,-2 red cells [65]. The antigen recognized by this antibody has become ER3 (208003) of the ER Collection.

Since 1995, 207001 (I1, I) has formed the I system and retains the symbol I1, and 209001 (GLOB1, P) has formed the Globoside system and retains the symbol GLOB1. The creation of the I and Globoside systems means that these two systems have identical symbols, I and GLOB, to those of Collections 207 and 209. This should not cause confusion, however, as I1 and GLOB1 cannot refer to 207001 and 209001, as those numbers are now obsolete. Collection 207 now contains only one antigen. These anomalies will be resolved when a separate carbohydrate collection is created.

\section{0 series, low-incidence antigens}

There are currently 19 antigens in the 700 series (Table 7). Since 1995, no new numbers have been added and 18 numbers have been made obsolete: 16 antigens have joined the Diego

Table 6 Collections of antigens

\begin{tabular}{|c|c|c|c|c|c|}
\hline \multicolumn{3}{|c|}{ Collection } & \multicolumn{3}{|l|}{ Antigen } \\
\hline No. & Name & Symbol & No. & Symbol & $\begin{array}{l}\text { Incidence } \\
\text { percentage }\end{array}$ \\
\hline \multirow[t]{2}{*}{205} & Cost & COST & 205001 & $\mathrm{Cs}^{\mathrm{a}}$ & 95 \\
\hline & & & 205002 & $\mathrm{Cs}^{\mathrm{b}}$ & 34 \\
\hline 207 & li & I & 207002 & i & * \\
\hline \multirow[t]{3}{*}{208} & Er & ER & 208001 & $\mathrm{Er}^{\mathrm{a}}$ & $>99$ \\
\hline & & & 208002 & $\mathrm{Er}^{\mathrm{b}}$ & $<1$ \\
\hline & & & 208002 & Er3 & $>99$ \\
\hline \multirow[t]{2}{*}{209} & & GLOB & 209002 & $\mathrm{P}^{\mathrm{k}}$ & $>99^{*}$ \\
\hline & & & 209003 & LKE & 98 \\
\hline \multirow[t]{2}{*}{210} & & & 210001 & $\operatorname{Le}^{c}$ & 1 \\
\hline & & & 210002 & $\operatorname{Le}^{d}$ & 6 \\
\hline \multirow[t]{2}{*}{211} & Vel & VEL & 211001 & Vel & $>99$ \\
\hline & & & 211002 & ABTI & $>99$ \\
\hline
\end{tabular}

*By standard serological tests, may appear to be low incidence. Obsolete collections: 201 Gerbich; 202 Cromer; 203 Indian; 204 Auberger;

206 Gregory; 211 Wright. 
Table 7 The700 series: low-incidence antigens

\begin{tabular}{llllll}
\hline No. & Name & Symbol & No. & Name & Symbol \\
\hline 700002 & Batty & $\mathrm{By}$ & 700040 & Rasmussen & RASM \\
700003 & Christiansen & $\mathrm{Chr}^{\mathrm{a}}$ & 700043 & Oldeide & $\mathrm{Ol}^{\mathrm{a}}$ \\
700005 & Biles & $\mathrm{Bi}$ & 700044 & & $\mathrm{JFV}$ \\
700006 & Box & $\mathrm{Bx}^{\mathrm{a}}$ & 700045 & Katagiri & $\mathrm{kg}$ \\
700017 & Torkildsen & $\mathrm{To}^{\mathrm{a}}$ & 700047 & Jones & JONES \\
700018 & Peters & $\mathrm{Pt}^{\mathrm{a}}$ & 700049 & & HJK \\
700019 & Reid & $\mathrm{Re}^{\mathrm{a}}$ & 700050 & & HOFM \\
700021 & Jensen & $\mathrm{Je}^{\mathrm{a}}$ & 700052 & & SARA \\
700028 & Livesay & $\mathrm{Li}^{\mathrm{a}}$ & 700054 & & REIT \\
700039 & Milne & & & & \\
\hline
\end{tabular}

Table 8 The 901 series: high-incidence antigens

\begin{tabular}{llllll}
\hline No. & Name & Symbol & No. & Name & Symbol \\
\hline 901002 & Langereis & Lan & 901012 & Sid & Sd $^{\text {a }}$ \\
901003 & August & $\mathrm{At}^{\mathrm{a}}$ & 901013 & Duclos & \\
901005 & & $\mathrm{Jr}^{\mathrm{a}}$ & 901014 & & $\mathrm{PEL}$ \\
901008 & & Emm & 901016 & & $\mathrm{MAM}$ \\
901009 & Anton & $\mathrm{AnWj}$ & & & \\
\hline
\end{tabular}

system (Table 5); 700015 (Rd) has become SC4; and 700053 (LOCR) has become RH55.

\section{Criteria for inclusion in the 700 series:}

(1) An incidence of $<1 \%$ in most populations tested.

(2) Distinction from all other numbered low-incidence antigens of the 700 series as well as those of the blood group systems and collections.

(3) Demonstration of inheritance through at least two generations.

\section{1 series, high-incidence antigens}

There are currently nine antigens in the 901 series (Table 8). Since 1995, two new antigens, both of high incidence, have been added: 901015 (ABTI) [63] and 901016 (MAM) [66], although 901015 (ABTI) has now become VEL2 of the 211 collection. Three antigens became the sole antigens of new blood group systems and their 901 numbers are obsolete: 901006 $\left(\mathrm{Ok}^{\mathrm{a}}\right)$ has become OK1; $901007(\mathrm{JMH})$ has become JMH1; and 901011 (MER2) has become RAPH1 (Table 1).

The gene encoding the $\beta 1,4-N$-acetylgalactosaminyltransferase responsible for $901012\left(\mathrm{Sd}^{\mathrm{a}}\right)$ antigen has been cloned $[67,68]$, but 901012 has not formed a new blood group system because the molecular basis for the $\mathrm{Sd}^{\mathrm{a}}$ polymorphism has not been determined.

\section{Criteria for inclusion in the 901 series:}

(1) An incidence of $>90 \%$ in most populations tested.

(2) Distinction from all other numbered high-incidence specificities.

(3) Demonstration that the antigen is lacking from the red cells of at least 2 sibs, i.e. that the negative phenotype is genetically determined.

\section{Obsolete numbers}

There is no recycling of blood group numbers: once a number has been allocated to a specificity, that number cannot be subsequently used for any other specificity. Consequently, if the number of a specificity becomes inappropriate, then that number becomes obsolete. Obsolete numbers are listed in Table 9.

\section{Procurement of ISBT numerical designations}

\section{Choice of symbol}

Symbols for designations of new specificities will consist of three to six on-line capital letters and must not duplicate, alphabetically or phonetically, any current or obsolete symbols shown in the tables. Also, symbols used in related fields, such as those used for platelet and leucocyte antigens, must be avoided. Symbols for specificities that may herald new blood group systems, and thus new genes, have the further constraint that they must differ from any symbols given to genes by the HUGO Nomenclature Committee (http://www. gene.ucl.ac.uk/nomenclature/).

\section{Procedures for acquisition of an ISBT number}

The initial stipulation is that materials for defining the new specificity should be available for either circulation or inhouse testing; the futility of defining a new specificity from which future new specificities cannot be distinguished is obvious. Proposals should be submitted with supporting data to the members of the Committee listed below, who are authorized to allocate numbers provisionally in consultation with the Chair. All decisions must be ratified by the Committee before being finalized.

- For a new blood group system or collection: Dr Geoff Daniels.

- For a specificity number within an established system: Dr Marion Reid for the MNS system; Dr Sylvano Wendel or Mrs Marilyn Moulds for the Rh system; Dr Jan Jørgensen for other systems.

- For a specificity number in a current collection: Dr Geoff Daniels.

- For a 700 number: Dr Teresa Zelinski.

- For a 901 number: Dr Geoff Daniels. 
Table 9 Obsolete numbers

\begin{tabular}{|c|c|c|c|c|c|}
\hline Obsolete no. & $\begin{array}{l}\text { Symbol or } \\
\text { previous symbol }\end{array}$ & Current no. & Obsolete no. & $\begin{array}{l}\text { Symbol or } \\
\text { previous symbol }\end{array}$ & Current no. \\
\hline 001005 & $\mathrm{H}$ & 018001 & 700010 & $\mathrm{Bp}^{\mathrm{a}}$ & 010010 \\
\hline 003002 & $P$ & 209001 & 700011 & Or & 002031 \\
\hline 003003 & $P^{k}$ & 209002 & 700012 & Gf & Obsolete \\
\hline 004013 & $\mathrm{Rh}^{\mathrm{A}}$ & Obsolete & 700013 & Wu & 010009 \\
\hline 004014 & $\mathrm{Rh}^{\mathrm{B}}$ & Obsolete & 700014 & $\mathrm{Jn}^{\mathrm{a}}$ & 010017 \\
\hline 004015 & $\mathrm{Rh}^{\mathrm{C}}$ & Obsolete & 700015 & $\mathrm{Rd}$ & 013004 \\
\hline 004016 & $\mathrm{Rh}^{\mathrm{D}}$ & Obsolete & 700016 & Heibel & Obsolete \\
\hline 004024 & $\mathrm{E}^{\mathrm{T}}$ & Obsolete & 700020 & $A n^{\mathrm{a}}$ & 020007 \\
\hline 004025 & $\mathrm{LW}$ & Obsolete, see system 16 & 700022 & $\mathrm{Mo}^{\mathrm{a}}$ & 010011 \\
\hline 004038 & Duclos & 901013 & 700023 & Hey & Obsolete \\
\hline 005010 & Singleton & Obsolete & 700024 & $\mathrm{RI}^{\mathrm{a}}\left(=\mathrm{L} s^{\mathrm{a}}\right)$ & 020006 \\
\hline 005015 & Anton & 901009 & 700025 & $\ln ^{\mathrm{a}}$ & 023001 \\
\hline 006008 & $\mathrm{Kw}$ & Obsolete & 700026 & $\mathrm{Fr}^{\mathrm{a}}$ & 010020 \\
\hline 006009 & $\mathrm{KL}$ & Obsolete & 700027 & $\mathrm{Rb}^{\mathrm{a}}$ & 010006 \\
\hline 006015 & $\mathrm{Kx}$ & 019001 & 700029 & $\mathrm{Vg}^{\mathrm{a}}$ & 010013 \\
\hline 016001 & $\mathrm{LW}_{1}$ phenotype & Obsolete & 700030 & $W d^{a}$ & 010005 \\
\hline 016002 & $\mathrm{LW}_{2}$ phenotype & Obsolete & 700031 & $\mathrm{Dh}^{\mathrm{a}}$ & 020008 \\
\hline 016003 & $\mathrm{LW}_{3}$ phenotype & Obsolete & 700032 & POLL & Obsolete \\
\hline 016004 & $\mathrm{LW}_{4}$ phenotype & Obsolete & 700033 & $O s^{a}$ & 002038 \\
\hline 020001 & $\mathrm{Ge} 1$ & Obsolete & 700034 & $\mathrm{Hg}^{\mathrm{a}}$ & 010012 \\
\hline Collection 201 & GE & System 020 & 700035 & $\mathrm{Tc}^{\mathrm{b}}$ & 021003 \\
\hline Collection 202 & CROMER & System 021 & 700036 & $\mathrm{Tc}^{\mathrm{c}}$ & 021004 \\
\hline Collection 203 & IN & System 023 & 700037 & NFLD & 010016 \\
\hline Collection 204 & $\mathrm{AU}$ & 005018 \&t 005019 & 700038 & $\operatorname{Hov}(=W u)$ & 700013 \\
\hline 205003 & $\mathrm{Yk}^{\mathrm{a}}$ & 022005 & 700041 & SW1 & 010021 \\
\hline 205004 & $\mathrm{Kn}^{\mathrm{a}}$ & 022001 & 700042 & WES (WES ${ }^{\mathrm{a}}$ ) & 021008 \\
\hline 205005 & $\mathrm{Kn}^{\mathrm{b}}$ & 022002 & 700046 & BOW & 010015 \\
\hline 205006 & $\mathrm{McC}^{\mathrm{a}}$ & 022003 & 700048 & FPTा & 004050 \\
\hline 205007 & $\mathrm{SI}^{\mathrm{a}}$ & 022004 & 700051 & ELO & 010008 \\
\hline Collection 206 & GY & 014003 \& 014004 & 700053 & LOCR & 004055 \\
\hline 207001 & I & 027001 & 700055 & WARR & 010007 \\
\hline Collection 211 & WR & 010003 \&t 010004 & 901004 & $\mathrm{Jo}^{\mathrm{a}}$ & 014005 \\
\hline 209001 & $\mathrm{P}$ & 028001 & 901006 & $\mathrm{Ok}^{\mathrm{a}}$ & 024001 \\
\hline 700001 & $\mathrm{Wr}^{\mathrm{a}}$ & 010003 & 901007 & JMH & 026001 \\
\hline 700004 & $S w^{a}$ & 010013 & 901010 & $W r^{b}$ & 010004 \\
\hline 700007 & $\mathrm{Ls}^{\mathrm{a}}$ & 020006 & 901011 & MER2 & 025001 \\
\hline 700008 & $\mathrm{Tr}^{\mathrm{a}}$ & 010019 & 901001 & Vel & 211001 \\
\hline 700009 & $\mathrm{~Wb}$ & 020005 & 901015 & ABTI & 211002 \\
\hline
\end{tabular}

\section{Conclusions}

Although the primary function of the Committee is to monitor and update the terminology, there are two main issues that need to be tackled in the future: updating and redefining the terminology for blood group genes and alleles; and devising a collection for those carbohydrate antigens that do not belong to a system.

The Committee strongly urges that all authors in the field of human red cell blood groups should use the terminology provided in Tables 1-8 in either the alphabetical/numerical format (e.g. FY2) or the 'popular' alternative format (e.g. Fy ${ }^{b}$ ). For clarity, it is often advisable when using the more traditional terminology to include the ISBT terminology in parentheses, for example $\mathrm{An}^{\mathrm{a}}$ (GE7).

All members of the Committee, listed in Appendix I, are prepared to handle requests for advice or assistance in any aspect of an investigation or to direct them to the most appropriate authority. The Chair of the Committee would be happy to receive any comments or criticisms of the terminology and would raise them at a Committee meeting. Membership of the Committee is open to colleagues who are considered 
international experts in the field of blood groups or related fields and who are prepared to participate in the activities of the Committee.

\section{Acknowledgements}

We are grateful to the following colleagues who have retired from the Committee since 1995: Prof. David Anstee, Prof. Jean-Pierre Cartron, Prof. Dr Wolfgang Dahr, Dr Peter Issitt, Dr Lief Kornstad, Dr Marie Lin, Dr Anatole Lubenko, Ms Delores Mallory, Dr Yasuto Okubo, Dr Siegfried Seidl, and Dr Graeme Woodfield.

\section{References}

1 Lewis M, Anstee DJ, Bird GWG, Brodheim E, Cartron J-P, Contreras M, Crookston MC, Dahr W, Daniels GL, Engelfriet CP, Giles CM, Issitt PD, Jørgensen J, Kornstad L, Lubenko A, Marsh WL, McCreary J, Moore BPL, Morel P, Moulds JJ, Nevanlinna H, Nordhagen R, Okubo Y, Rosenfield RE, Rouger Ph, Rubinstein P, Salmon Ch, Seidl S, Sistonen P, Tippett P, Walker RH, Woodfield G, Young S: Blood group terminology 1990. From the ISBT Working Party on Terminology for Red Cell Surface Antigens. Vox Sang 1990; 58:152-169

2 Daniels GL, Anstee DJ, Cartron JP, Dahr W, Issitt PD, Jørgensen J, Kornstad L, Levene C, Lomas-Francis C, Lubenko A, Mallory D, Moulds JJ, Okubo Y, Overbeeke M, Reid ME, Rouger P, Seidl S, Sistonen P, Wendel S, Woodfield G, Zelinski T: Blood Group Terminology 1995: From the ISBT Working Party on Terminology for Red Cell Surface Antigens. Vox Sang 1995; 69:265-279

3 Daniels GL, Anstee DJ, Cartron JP, Dahr W, Henry S, Issitt PD, Jørgensen J, Judd WJ, Kornstad L, Levene C, Lomas-Francis C, Lubenko A, Mallory D, Moulds JM, Moulds JJ, Okubo Y, Overbeeke M, Reid ME, Rouger P, Seidl S, Sistonen P, Wendel S, Zelinski T: Terminology for red cell surface antigens. Makuhari report. Vox Sang 1996; 71:246-248

4 Daniels GL, Anstee DJ, Cartron JP, Dahr W, Garratty G, Henry S, Jørgensen J, Judd WJ, Kornstad L, Levene C, Lomas-Francis C, Lubenko A, Moulds JJ, Moulds JM, Moulds M, Overbeeke M, Reid ME, Rouger P, Scott M, Seidl S, Sistonen P, Tani Y, Wendel S, Zelinski T: Terminology for red cell surface antigens. ISBT Working Party Oslo report. Vox Sang 1999; 77:52 - 57

5 Daniels GL, Anstee DJ, Cartron JP, Dahr W, Fletcher A, Garratty G, Henry S, Jørgensen J, Judd WJ, Kornstad L, Levene C, Lin M, Lomas-Francis C, Lubenko A, Moulds JJ, Moulds JM, Moulds M, Overbeeke M, Reid ME, Rouger P, Scott M, Sistonen P, Smart E, Tani Y, Wendel S, Zelinski T: Reports and guidelines. International Society of Blood Transfusion Working Party on terminology for red cell surface antigens. Vox Sang 2001; 80:193-196

6 Daniels GL, Cartron JP, Fletcher A, Garratty G, Henry S, Jørgensen J, Judd WJ, Levene C, Lin M, Lomas-Francis C, Moulds JJ, Moulds JM, Moulds M, Overbeeke M, Reid ME, Rouger P, Scott M, Sistonen P, Smart E, Wendel S, Zelinski T: International Society of Blood Transfusion Commitee on terminology for red cell surface antigens. Vox Sang 2003; 84:244-247

7 Olivès B, Mattei M-G, Huet M, Neau P, Martial S, Cartron JP, Bailly P: Kidd blood group and urea transport function of human erythrocytes are carried by the same protein. J Biol Chem 1995; 270:15607-15610

8 Sidoux-Walter F, Lucien N, Olivès B, Gobin R, Rousselet G, Kamsteeg EJ, Ripoche P, Deen PM, Cartron JP, Bailly P: At physiological expression levels the Kidd blood group/urea transporter protein is not a water channel. J Biol Chem 1999; 274:3022830235

9 Wagner FF, Poole J, Flegel WA: The Scianna antigens including Rd are expressed by ERMAP. Blood 2002; 101:752-757

10 Eiberg H, Mohr J: Dombrock blood group (DO): assignment to chromosome 12p. Hum Genet 1996; 98:518-521

11 Gubin AN, Njoroge JM, Wojda U, Pack SD, Rios M, Reid ME, Miller JL: Identification of the Dombrock blood group glycoprotein as a polymorphic member of the ADP-ribosyltransferase gene family. Blood 2000; 96:2621-2627

12 Spring FA, Homes CH, Simpson KL, Mawby WJ, Mattes MJ, Okubo Y, Parsons SF: The $\mathrm{Ok}^{\mathrm{a}}$ blood group antigen is a marker for the M6 leukocyte activation antigen, the human homolog of 0X-47 antigen, basigin and neurothelin, an immunoglobulin superfamily molecule that is widely expressed in human cells and tissues. Eur J Immunol 1997; 27:891-897

13 Daniels GL, Tippett P, Palmer DK, Miller YE, Geyer D, Jones C: MER2: a red cell polymorphism defined by monoclonal antibodies. Vox Sang 1987; 52:107-110

14 Daniels GL, Levene C, Berrebi A, Schechter Y, Moulds M, Sela R, Poole J, Lacey P, Atkins CJ: Human alloantibodies detecting a red cell antigen apparently identical to MER2. Vox Sang 1988; 55:161- 164

15 Karamatic Crew V, Burton N, Kagan A, Green CA, Levene C, Flinter F, Brady LR, Daniels G, Anstee DJ: CD151, the first member of the tetraspanin (TM4) superfamily detected on erythrocytes, is essential for the correct assembly of human basement membranes in kidney and skin. Blood 2004; 104: 2217-2223.

16 Mudad R, Rao N, Angelisova P, Horejsi V, Telen MJ: Evidence that CDw108 membrane protein bears the JMH blood group antigen. Transfusion 1995; 35:566-570

17 Yamada A, Kubo K, Takeshita T, Harashima N, Kawano K, Mine T, Sagawa K, Sugamura K, Itoh K: Molecular cloning of a glycosylphosphatidylinositol-anchored molecule CDw108. J Immunol 1999; 162:4094-4100

18 Yu L-C, Twu Y-C, Chang C-Y, Lin M: Molecular basis of the adult i phenotype and the gene responsible for the expression of the human blood group I antigen. Blood 2001; 98:3840-3845

19 Yu L-C, Twu Y-C, Chou M-L, Reid ME, Gray AR, Moulds JM, Chang C-Y, Lin M: The molecular genetics of the human I locus and molecular background explaining the partial association of the adult I phenotype with congenital cataracts. Blood 2003; 101:2081-2088

20 Okajima T, Nakamura Y, Uchikawa M, Haslam DB, Numata Furukawa K, Urano T, Furukawa K: Expression cloning of human globoside synthase cDNAs. Identification of $\beta 3 \mathrm{Gal}-\mathrm{T} 3$ as UDP- $N$-acetylgalactosamine: globotriosylceramide $\beta 1,3-N-$ acetylgalactosaminyltransferase. J Biol Chem 2000; 275:4049840503

21 Hellberg Å, Poole J, Olsson ML: Molecular basis of the globoside-deficient $\mathrm{P}^{\mathrm{k}}$ blood group phenotype. Identification of four inactivating mutations in the UDP- $N$-acetylgalactosamine: 
globotriaosylceramide $3-\beta-N$-acetylgalactosaminyltransferase gene. J Biol Chem 2002; 277:29455-29459

22 Daniels GL, DeLong EN, Hare V, Johnson ST, LePennec PY, Mallory D, Marshall MJ, Oliver C, Spruell P: GIL: a red cell antigen of very high frequency. Immunohematology 1998; 14:49-52

23 Roudier N, Ripoche P, Gane P, Le Pennec PY, Daniels G, Cartron JP, Bailly P: AQP3-deficiency in humans and molecular basis of a novel blood group system, GIL. J Biol Chem 2002; $277: 45854-$ 45859

24 den Dunnen JT, Antonarakis E: Nomenclature for the description of human sequence variations. Hum Genet 2001; 109:121 - 124

25 Garratty G, Dzik W, Issitt PD, Lublin DM, Reid ME, Zelinski T: Terminology for blood group antigens and genes-historical origins and guidelines in the new millennium. Transfusion 2000; 40:477-489

26 Poole J, Banks JA, Bruce LJ, Ring SM, Tanner MJA, Levene C: A novel glycophorin A polymorphism affecting $\mathrm{Wr}^{\mathrm{b}}$ expression. Transfusion 1995; 35:40S (Abstract)

27 Jarolim P, Moulds JM, Moulds JJ, Rubin HL, Dahr W: MARS and AVIS blood group antigens: polymorphism of glycophorin A affects band 3 glycophorin A interaction. Blood 1996; 88:182a (Abstract)

28 Spruell P, Moulds JJ, Martin M, Gilcher R0, Howard PB, Blumenfeld 00: An anti-En ${ }^{\text {TTS }}$ detected in the serum of an $M i^{I}$ homozygote. Transfusion 1993; 33:848-851

29 Iwamura K, Furukawa K, Uchikawa M, Sojka BN, Kojima Y, Wiels J, Shiku H, Urano T, Furukawa K: The blood group P1 synthase gene is identical to the Gb3/CD77 synthase gene: a clue to the solution of the P1/P2/, p. puzzle. J Biol Chem 2003; 45:44429-44438

30 Hellberg $\AA$ : Sixteen polymorphic sites in the $5^{\prime} / 3^{\prime}$-UTR of the $P^{k}$ gene do not correlate with P1/P2 phenotypes. Vox Sang 2004; 87 (suppl 3):81 (Abstract)

31 Tippett P, Lomas-Francis C, Wallace M: The Rh antigen D: partial D antigens and associated low incidence antigens. Vox Sang 1996; 70:123-131

32 Green C, Coghlan G, Bizot M, Kasulke D, Bombail-Girard M, Wallace M, Lomas-Francis C, Daniels G: JAHK: a low frequency antigen associated with the $\mathrm{r}^{\mathrm{G}}$ complex of the Rh blood group system. Transfus Med 2002; 12:55-61

33 Reid ME, Storry JR, Sausais L, Tossas E, Rios M, Hue-Roye K, Gloster ES, Miller ST, Wolf C, Lomas-Francis C: DAK, a new lowincidence antigen in the $\mathrm{Rh}$ blood group system. Transfusion 2003; 43:1394-1397

34 Coghlan G, Zelinski T: DNA microsatellite and linkage analysis supports the inclusion of LOCR in the Rh blood group system. Transfusion 2003; 43:440-444

35 Westhoff CM, Storry JR, Walker P, Lomas-Francis C, Reid ME: A new hybrid RHCE gene (CeNR) is responsible for expression of a novel antigen. Transfusion 2004; 44:1047 - 1051

36 Scott ML, Anstee DJ, Cartron J-P, Dahr W, Daniels G, Fletcher A, Garratty G, Henry S, Jorgensen J, Judd WJ, Levene C, Lin M, Lomas-Francis C, Moulds JJ, Moulds JM, Moulds M, Overbeeke M, Reid ME, Rouger P, Sistonen P, Smart E, Tani Y, Wendel S, Zelinski T: International Society of Blood Transfusion Working Party on Terminology for Red Cell Surface Antigens - terminology for epitopes and variant antigens of Rh D (004001; RH1). Vox Sang 2004; in press
37 Lomas C, McColl K, Tippett P: Further complexities of the Rh antigen D disclosed by testing category DII cells with monoclonal anti-D. Transfus Med 1993; 3:67-69

38 Karamatic Crew V, Poole J, Banks J, Reed M, Daniels G: LU21: a new antigen in the Lutheran blood group system. Vox Sang 2004; 87:109-113.

39 Lee S, Reid ME, Redman CM: Point mutations in KEL exon 8 determine a high-incidence (RAZ) and a low-incidence (KEL25, VLAN) antigen of the Kell blood group system. Vox Sang 2001; $81: 259-263$

40 Grey D, Poole J, Martin P, Condon J, Allwright J, 0’Day S, Daniels G: Haemolytic disease of the newborn caused by a new Kell antigen. Transfus Med 2003; 13 (suppl 1):30 (Abstract)

41 Lee S: Molecular basis of Kell blood group phenotypes. Vox Sang 1997; 73: 1-11 and Vox Sang 1998; 74: 58

42 Henry S, Oriol R, Samuelsson B: Lewis histo-blood group system and associated secretory phenotypes. Vox Sang 1995; 69:166-182

43 Bruce LJ, Zelinski T, Ridgwell K, Tanner MJA: The low-incidence blood group antigen, $\mathrm{Wd}^{\mathrm{a}}$, is associated with the substitution $\mathrm{Val}_{557} \rightarrow$ Met in human erythrocyte band 3 (AE1). Vox Sang 1996; 71:118-120

44 Jarolim P, Murray JL, Rubin HL, Smart E, Moulds JM: Blood group antigens $\mathrm{Rb}^{\mathrm{a}}, \mathrm{Tr}^{\mathrm{a}}$, and $\mathrm{Wd}^{\mathrm{a}}$ are located in the third ectoplasmic loop of erythroid band 3. Transfusion 1997; 37:607-615

45 Jarolim P, Murray JL, Rubin HL, Coghlan G, Zelinski T: A Thr ${ }_{552}$ $\rightarrow$ Ile substitution in erythroid band 3 gives rise to the Warrior blood group antigen. Transfusion 1997; 37:398-405

46 Zelinksi T, Punter F, McManus K, Coghlan G: The ELO blood group polymorphism is located in the putative first extracellular loop of human erythrocyte band 3. Vox Sang 1998; 75:63-65

47 Jarolim P, Rubin HL, Zakova D, Storry J, Reid ME: Characterization of seven low incidence blood group antigens carried by erythrocyte band 3 protein. Blood 1998; 92:4836-4843

48 Zelinski T, McManus K, Punter F, Moulds M, Coghlan G: A $\mathrm{Gly}_{565} \rightarrow$ Ala substitution in human erythrocyte band 3 accounts for the Wu blood group polymorphism. Transfusion 1998; 38:745-748

49 Zelinski T, Rusnak A, McManus K, Coghlan G: Distinctive Swann blood group genotypes: molecular investigations. Vox Sang 2000; 79:215-218

50 Poole J, Bruce LJ, Hallewell H, Kusnierz-Alejska G, Zupanska B, Daniels GL, Tanner MJA: Erythrocyte band 3 mutation Pro561 $\rightarrow$ Ser givers rise BOW antigen Pro566 $\rightarrow$ Ala to a novel antigen KREP. Transfus Med 1998; 8 (suppl 1):17 (Abstract)

51 McManus K, Pongoski J, Coghlan G, Zelinski T: Amino acid substitutions in human erythroid protein, band 3 account for the low-incidence antigens NFLD and BOW. Transfusion 2000; 40:325-329

52 Poole J, Hallewell H, Bruce L, Tanner MJA, Zupanska B, Kusnierz-Alejska G: Identification of two new Jn(a+) individuals and assignment of $\mathrm{Jn}^{\mathrm{a}}$ to erythrocyte band 3. Transfusion 1997; 37:90S (Abstract)

53 McManus K, Lupe K, Coghlan G, Zelinski T: An amino acid substitution in the putative second extracellular loop of RBC band 3 accounts for the Froese blood group polymorphism. Transfusion 2000; 40:1246- 1249

54 Tippett P, Ellis N: The Xg blood group system: a review. Transfus Med Rev 1998; 12:233-257 
55 Uchikawa M, Tsuneyama H, Tadokoro K, Juji T, Yamada M, Maeda Y: An alloantibody to 12E7 antigen detected in 2 healthy donors. Transfusion 1995; 35:23S (Abstract)

56 Hue-Roye K, Chaudhuri A, Velliquette RW, Thomas R, Balk M, Reid ME: A novel high prevalence antigen in the Scianna blood group system. Vox Sang 2004; 87 (suppl 3):40 (Abstract)

57 Yabe R, Uchikawa M, Tuneyama H, Ogasawara K, Toyoda T, Suzuki Y, Shimizu H, Uchida S, Nakajima K: IS: a new Gerbich blood group antigen located on the GPC and GPD. Vox Sang 2004; 87 (suppl 3):79 (Abstract)

58 Storry JR, Sausais L, Hue-Roye K, Mudiwa F, Ferrer Z, Blajchman MA, Lublin DM, Ma B-W, Miquel JF, Nervi F, Pereira J, Reid ME: GUTI: a new antigen in the Cromer blood group system. Transfusion 2003; 43:340-344

59 Banks J, Poole J, Ahrens N, Seltsam A, Salama A, Hue-Roye K, Storry JR, Palacajornsuk P, Ma B-W, Lublin DM, Reid ME: SERF: a new antigen in the Cromer blood group system. Transfus Med 2004; 14:313-318

60 Hue-Roye K, Powell V, Barnes J, Chung A, Fung Kee Fung K, Kinney J, Lublin D, Belaygorod. L, Reid M: ZENA: A new high prevalence Cromer blood group antigen. Transfusion 2004; 44: 26A (Abstract)

61 Moulds JM, Zimmerman PA, Doumbo OK, Kassambara L, Sagara I, Diallo DA, Atkinson JP, Krych-Goldberg M, Hauhart RE, Hourcade DE, McNamara DT, Birmingham DJ, Rowe JA, Moulds JJ, Miller LH: Molecular identification of Knops blood group polymorphisms found in long homologous region D of complement receptor 1. Blood 2001; 97:2879-2885

62 Moulds JM, Zimmerman PA, Doumbo OK, Diallo DA, Atkinson JP,
Krych-Goldberg M, Hourcade DE, Moulds JJ: Expansion of the Knops blood group system and subdivision of $\mathrm{Sl}^{\mathrm{a}}$. Transfusion 2002; 42:251-256

63 Schechter Y, Chezar J, Levene C, Poole J, Moulds M, Daniels G: ABTI (901015), a new red cell antigen of high frequency. Transfusion 1996; 36:25S (Abstract)

64 Banks J, Poole J, Das Gupta C, Lonicer C, Salama A: Two new cases of nti-ABTI showing an association between ABTI and Vel. Vox Sang 2004; 87 (suppl 3):38 (Abstract)

65 Arriaga F, Mueller A, Rodberg K, Ciesielski D, Poole J, Banks J, de La Rubia J, Carpio N, Marty ML, Garratty G: A new antigen of the Er collection. Vox Sang 2003; 84:137-139

66 Montgomery WM, Jr, Nance SJ, Donnelly SF, Brady TW, Anderson G, Mintz PD, Moulds MK, Daniels GL, Spring FA, Molina N, de Asis EA, Olivares E: MAM: a 'new' high-incidence antigen found on multiple cell lines. Transfusion 2000; 40:1132- 1139

67 Montiel M-D, Krzewinski-Recchi M-A, Delannoy P, HarduinLepers A: Molecular cloning, gene organization and expression of human UDP-GalNAc: Neu5Ac $\alpha 2-3 \mathrm{Gal} \beta-\mathrm{R} \quad \beta 1,4-N$ acetylgalactosaminyltransferase responsible for the biosynthesis of the blood group $\mathrm{Sd}^{\mathrm{a}} / \mathrm{Cad}$ antigen: evidence for an unusual extended cytoplasmic domain. Biochem J 2003; 373:369379

68 Presti LL, Cabuy E, Chiricolo M, Dall'olio F: Moleculer cloning of the human $\beta 1,4 N$-acetylgalactosaminyltransferase responsible for the biosynthesis of the Sol ${ }^{\text {a }}$ histo-blood group antigen: the sequence predicts a very long aytoplasmic domain. $J$ Biochem 2003; 134:675-682 


\section{Appendix I}

Addresses and fax numbers of Committee members

Dr G. L. Daniels

Dr A. Fletcher

Prof. G. Garratty

Prof. S. Henry

Dr J. Jørgensen

Prof. W. J. Judd

Dr C. Levene

Ms C. Lomas-Francis

Mr J. J. Moulds

Dr J. M. Moulds

Ms M. Moulds

Dr M. A. M. Overbeeke

Dr M. E. Reid

Dr Ph Rouger

Dr M. Scott

Dr P. Sistonen

Mrs E. Smart

Dr Y. Tani

Dr S. Wendel

Dr T. Zelinski
Bristol Institute for Transfusion Sciences, Southmead Road, Bristol BS10 5ND, UK. geoff.daniels@nbs.nhs.uk

Growing your Knowledge, P0 Box 716, Spit Junction, NSW 2088, Australia. af@growingyourknowledge.com.au

American Red Cross Blood Services, Los Angeles-Orange Counties Region, 1130 South Vermont Avenue, Los Angeles, CA 90006, USA.garratty@usa.redcross.org

Biotechnology Research Centre, Auckland University of Technology, Private Bag 92006, Auckland 1020, New Zealand.

kiwi@aut.ac.nz

Regional Blood Transfusion Center, Department of Clinical Immunology, University Hospital, Skejby, DK-8200 Århus N, Denmark.jjo@sks.aaa.dk

Department of Pathology, University Hospitals UH-2G332, 1500 E Medical Center Drive, Ann Arbor, Michigan 48109-0054 USA. johnjudd@med.umich.edu

Reference Laboratory for Immunohematology and Blood Groups, National Blood Services Centre, Magen David Adom, Tel Hashomer 52621, Israel. cyril@cc.huji.ac.il

New York Blood Center, 310 East 67th Street, New York, NY 10021, USA. clomas-francis@nybloodcenter.org

Ortho-Clinical Diagnostics, 1001 US Highway 202, Raritan, NJ 08869-0606, USA.jmoulds@ocdus.jnj.com

Drexel University College of Medicine, 2900 Queen Lane, Philadelphia, PA 19129, USA. moulds@drexel.edu

Gamma Biologicals Inc (subsidiary of Immunocor Inc), 3700 Mangum Road, Houston, TX 77092, USA.

mmoulds@immucor.com

Sanquin Blood Supply, Diagnostic Services, Department of Immunohematology, Plasmanlaan 125, 1066 CX, Amsterdam, the Netherlands.

m.overbeeke@sanquin.nl

New York Blood Center, 310 East 67th Street, New York, NY 10021, USA. mreid@nybloodcenter.org

Centre national de Référence pour les Groupes sanguines, CNTS St Antoine, 53 boulevard Diderot, F-75571 Paris Cedex 13 , France.tcb_ints@ints.fr

International Blood Group Reference Laboratory, Southmead Road, Bristol BS10 5ND, UK. marion.scott@nbs.nhs.uk Finnish Red Cross Blood Transfusion Service, Kivihaantie 7, SF-00310, Helsinki 31, Finland.

pertti.sistonen@bts.redcross.fi

South African National Blood Service, East Coast Region, Private Bag X9044, Pinetown 3600, South Africa.

smarte@ecr.sansb.org.za

Osaka Red Cross Blood Center, Morinomiya 2-4-43, Joto-ku, Osaka, 536-8505, Japan. taniy@sannet.ne.jp

Blood Bank, Hospital Sirio-Libanes, Rua Dona Adma Jafet 91, 29 Andar, São Paulo, Brazil. snwendel@uninet.com.br

Rh Laboratory, Room P009, Pathology Building, 770 Bannatyne Avenue, Winnipeg, Manitoba R3E 0W3, Canada.

zelinski@ms.umanitoba.ca 